\title{
Athens and beyond: Soviet psychiatric abuse and the World Psychiatric Association
}

\author{
Sidney Bloch, Associate Professor, Department of Psychiatry, University of Melbourne, \\ Australia
}

The recent Eighth World Congress of the World Psychiatric Association (WPA), held between 12 and 19 October 1989 in Athens, was reminiscent of the previous World Congress in 1983 in Vienna, and the one before that in 1977 in Honolulu. Once again the issue of the Soviet political misuse of psychiatry reared its ugly head, and dominated the Association's proceedings. In 1977 the critical debate revolved around what position the WPA should adopt concerning the abuse. In a cliff-hanger vote, the WPA passed a resolution condemning the political misuse of psychiatry but explicitly citing the Soviet case (Bloch \& Reddaway, 1984). In the absence of any improvement in the situation by the time of Vienna and in the virtual certainty that the Russians would have been expelled from the organisation, the Soviet Psychiatric Society resigned from its membership in January 1983. In order to forestall a precipitous and premature readmission, the Royal College of Psychiatrists proposed at the Vienna Congress that the Soviets would be welcomed back into the fold but only when they had demonstrated "sincere cooperation", and when there had been concrete evidence of "amelioration" of the abuse.

Thus, the salient question in Athens was whether the conditions embodied in the Vienna Resolution had been adequately met. It emerged in the months leading up to the Congress that opinion was divided on the issue. The Danish Psychiatric Association, for example, submitted a resolution calling for unconditional readmission (the only society in fact to do so). Several national associations, including the Royal College, the West German Psychiatric Association, the Australasian College and the Swiss Psychiatric Association, held an opposite view, insisting that the Soviet Society should not be admitted until specific conditions had been satisfied; these included the release of all dissenters unjustifiably detained in mental hospitals, and the dissociation by the authorities from the past abuse and their commitment to prevent its repetition. An intermediate position was taken by a number of other member societies; four French psychiatric associations, for example, argued that the ad hoc membership conferred upon the Russians by the WPA's Executive Committee in March 1989 should continue until the abuse had been brought to an end. A similar position was adopted by the American Psychiatric Association.

The Russians, for their part, were determined to regain membership. Their delegation was composed of several high-ranking establishment figures who, undoubtedly, had been instructed to do all they could to ensure success. Among them were Professor Nikolai Zharikov, the chairman of the All-Union Society of Psychiatrists and Narcologists, and head of the delegation; Professor Marat Vartanyan, Director of the All-Union Research Centre for Mental Health and a long-standing defender of Soviet psychiatry; and Dr Alexander Karpov, Chief Psychiatrist in the Federal Ministry of Health. Revealingly, two senior psychiatrists who would have almost certainly proved an embarrassment in Athens, were left at home - Professor Georgy Morozov, the Director of the Serbsky Forensic Psychiatric Institute, and late Chairman of the All-Union Society, and active participant in the abuses; and Dr Alexander Churkin, the sacked Chief Psychiatrist in the Federal Health Ministry who had, a year earlier, invented the term "hyperdiagnosis" to explain away cases of abuse. Rather unconvincingly, he had commented: “... I have to admit that I have sometimes stumbled upon cases of so-called 'hyperdiagnosis' where the symptoms and the severity of the mental disturbance were less pronounced than those diagnosed by the psychiatrist" (Novoye Vrema, No. 43, 1988).

But the most important and central Russian figure in Athens was not a psychiatrist at all. Professor Yuri Reschetov, a lawyer, and Director of the Department of Humanitarian Problems and Human Rights of the USSR's Ministry of Foreign Affairs, had obviously been assigned by high political authority, mainly from within the Ministry of Foreign Affairs, to argue the Soviet case. He proved to be a feisty character, vigorous in all exchanges with those Western psychiatrists who challenged him, but at the same time manifesting a sense of unease about whether he would succeed in his mission. I surmise that Reschetov had been instructed by his seniors as follows: "We need desperately to shuck off this embarrassing pariah status, and we must gain international recognition and respectability at all costs. So, deploy every tactic you can devise in order to achieve readmission". 
I had several conversations with Professor Reschetov during the Congress. Earlier on, he attempted to impress upon me that substantial reforms in Soviet psychiatry were taking place. Granted, not all was right but more time was needed to complete the process. Membership of the WPA would help considerably in this regard. In our final discussion on the day of the vote in the Association's General Assembly, I sought to clarify how the WPA might be assured of the completion of the reform process. Bristling at this challenge, Reschetov retorted that whatever position the WPA took, the Soviets would persist with change, and if necessary go it alone. Overall, his approach had been a curious mix of ingratiation and bravura.

\section{The Lukacher memorandum}

The main "diplomatic" thrust came in the form of a memorandum disseminated by the Soviet Psychiatric Society at the beginning of the Congress. It referred to recent reforms in Soviet psychiatry including, inter alia, the new mental health legislation of March 1988 with its provision of the right of appeal to deal with unwarranted hospitalisation; the establishment of an independent commission comprising psychiatrists, lawyers and social workers to monitor cases of psychiatric misuse; and the transfer of the special psychiatric hospitals (prison psychiatric hospitals) from the Ministry of the Interior to the Ministry of Health. The removal of two Articles from the criminal code concerning anti-Soviet propaganda and slander of the State would make it impossible for further deployment of forensic psychiatric examinations in the context of socio-political dissent. In the most explicit reference to the use of psychiatry to suppress such dissent, the memorandum cited two previous key WPA resolutions, namely the one passed in Honolulu which had condemned abuse and made specific mention of the USSR; and the 1983 resolution calling for amelioration of the abuse as a condition of readmission. Furthermore, the Soviet Psychiatric Society expressed its determination to put an end to past cases where psychiatry was used for purposes other than medical ones. (Memorandum of the All-Union Society of Psychiatrists and Narcologists, signed by Professor G. Lukacher, October 1989).

After the Soviet delegation had been given the opportunity to meet with the WPA's Executive and Advisory Committee in order to elaborate on the Lukacher memorandum, it became a matter of concern to a group of delegates (particularly those from the Royal College, and the American, West German and Dutch Associations) that their colleagues in the General Assembly might not be offered a sufficiently accurate picture of current Soviet developments. The suggestion was then made to arrange an exchange between a representative of the official Soviet delegation and Dr Semyon Gluzman (1989). Dr Gluzman was in Athens representing the newlyformed Independent Psychiatric Association, a group formed in March 1989 and openly critical of the official psychiatric establishment for its lack of acknowledgement and condemnation of psychiatric abuse. [It will be recalled that Dr Gluzman served a ten-year sentence in the 1970s for his criticism of Soviet psychiatric practices. In recognition of his courage and commitment to ethical psychiatry, Gluzman was made a Distinguished Fellow of the American Psychiatric Association in 1979, and an Honorary Member of the Royal College in 1980 (Bloch \& Reddaway, 1984)].

Thus it was that an extraordinary general meeting of the General Assembly was convened on 15 October. The debate that made up this meeting did not exactly follow the Oxford Union's rules! The agreed-upon allocation of an hour to each side turned out to be 90 minutes for the Soviet delegation and 30 minutes for Gluzman. The imbalance of the teams was also striking, with Gluzman pitted against eight opponents.

The "official" line was very much a reiteration of the contents of the Lukacher memorandum. For his part, Dr Gluzman did not wish to negate the positive changes that were beginning to take place in the USSR. Moreover, he was optimistic about further desirable developments. But the open discussion about the state of Soviet psychiatry in the media including even a critical commentary in Kommunist, the theoretical and political journal of the Central Committee of the Communist Party (No. 13, 1989), was not matched by an equally open discussion among the ranks of the official psychiatric leadership. On the contrary, they had explicitly disapproved of the efforts of the media (Reddaway, 1989). Specifically, the facts of psychiatric abuse published in the press had not received any investigatory attention from the Ministry of Health (ironically, the Ministry's Chief Psychiatrist, Dr Karpov, was sitting opposite and would have been a key figure in any such investigation). Gluzman proceeded to refer to the published material as well as to a detailed report he had prepared in response to the Lukacher memorandum. In the latter, he took up each of the memorandum's points, carefully arguing how he saw such aspects as the new mental health laws, the status of the special psychiatric hospitals, and the proposal for an independent psychiatric commission.

It was impossible to determine who had "won" the debate. More relevant though was the opportunity it had provided for delegates of the WPA member societies to gain a more thorough understanding of the issues surrounding the readmission question. 


\section{The Soviet press conference}

Although the memorandum ostensibly constituted an admission that abuse had taken place and a form of dissociation from it, this was not echoed at a press conference convened by the Soviet delegation on 16 October. On the contrary, the panel was uniformly defensive and evasive. Following a lengthy and detailed account by Dr Karpov of Soviet psychiatric reforms - much along the lines of the memorandum - in which he emphasised the merits of the new mental health legislation and in particular the legal safeguards for patients, other panellists elaborated on what they regarded as positive facets of the new developments. Up to this point, one could not help but be persuaded of a Soviet commitment to usher in a new reformist era.

But then, abruptly, the bluntest of questions disrupted this sense of optimism. The question was posed by Dr Anatoly Koryagin, the celebrated dissenting psychiatrist. [He had served six years of a 12 year sentence, until given an amnesty in 1987, and had been made an Honorary Member of the Royal College in 1983 for his outstanding commitment to psychiatric ethics]. Had political psychiatric abuse occurred or not? Professor Alexander Tiganov, who took a prominent role in the press conference, replied hesitatingly that "such cases" could have taken place during the period of stagnation "but there was a need to distinguish between psychiatric, legal and political aspects;" furthermore, it was hoped that "it" would not recur in the future. Professor Haug, an Estonian and, interestingly, a Deputy in the Soviet Parliament, also referred to the pre-perestroika period when, he conceded, there had been problems; "now was the time to look forward", he maintained.

Dr Koryagin persevered with his challenge. These replies, he countered, failed to clarify whether an admission was being made that Soviet psychiatry had been misused for political purposes. On the one hand, the Lukacher memorandum appeared to recognise the validity of the WPA's Resolutions of 1977 and 1983. On the other hand, it was a matter of record that in the Soviet Psychiatric Society's letter of resignation of 1983, the signatories had accused the WPA of becoming politicised, and had referred particularly to the "slanderous" campaign of the Royal College and the American Psychiatric Association. (See Appendix V, Bloch \& Reddaway, 1984). Could the delegation clarify where it stood?

No offer of clarification followed. The press conference soon ended in an atmosphere of tension as the Royal College's delegate, Dr Jim Birley, insisted on such clarification. Not only did he wish to know whether the Royal College's attitude to the abuse was still regarded by the Soviet Society as slander but also whether an apology would be forthcoming. This challenge-to elicit an unambiguous statement about the occurrence of abuse - could not easily be evaded. Professor Haug could himself not offer a clarificatory response but would convey Dr Birley's request to the original chief signatory, Professor Georgy Morozov.

Ironically, a letter of apology was forwarded to $\mathrm{Dr}$ Birley a day later in which it was stated that: "The All-Union Society unreservedly withdraws the statement referring to the Royal College of Psychiatrists and to the American Psychiatric Association as contained in the letter addressed to all members of societies at the WPA on 31 January 1983 and signed by G. Morozov. It was emotional and incorrect". Clearly, an attempt had been made to mollify $\mathrm{Dr}$ Birley but the apology still remained short of an admission that abuse had taken place. This ambiguity was to become a crucial feature of the debate in the General Assembly on the evening of 17 October.

\section{The General Assembly debate on readmission}

Professor Costas Stefanis, the WPA's President, launched the proceedings by reminding delegates of the Association's 1983 Resolution. The pivotal issue before the General Assembly was whether the Soviet Society had provided concrete evidence of the amelioration of the abuse of psychiatry. If this were the case, the Society should be readmitted as a full member. Although indicating that it was up to the delegates to decide and that his task was confined to the setting of procedure, he promptly influenced the course of the debate by referring to the position adopted by the Association's Executive Committee. As was by then well known, Stefanis commented, the Executive Committee had granted ad hoc membership, as permitted by the WPA's statutes, to the Soviet Society earlier in the year, four members voting for and two abstaining. The same four were still in favour of granting full membership. The WPA's Advisory Committee had also had the opportunity to confer and had decided, by a large majority, that unconditional readmission was appropriate. At this juncture it seemed that little stood in the way of a comparable decision by the delegates of the member societies.

Dr Birley immediately launched a counter argument by raising what he saw as a paradox: it was impossible to comment on amelioration of an abuse which the Soviet Psychiatric Society had not acknowledged in the first place. This position had not altered in Athens itself since the Russians had continued to fudge the question. Professor Stefanis intervened at this stage by intimating that all delegates had received ample material about the state of the abuse, including the Lukacher memorandum. As a result they should be well placed to assess the current situation, including the Soviet position. 
Dr Melvin Sabshin, the Medical Director of the American Psychiatric Association (and one of the two members of the Executive Committee who had abstained from voting for ad hoc membership earlier in the year), asserted that, notwithstanding the documentation cited by Stefanis, Birley was correct inasmuch as the Russian delegation had consistently declined to make a statement about whether abuse had occurred or not. Would the ad hoc Soviet delegate wish to remedy the matter there and then?

Dr Pyotr Morozov, the Soviet Society's International Secretary, was then given the floor. He did in fact wish to make a statement on behalf of his delegation. It contained five points, which are quoted in full because of their significance:

"1. The All-Union Society of Psychiatrists and Narcologists [the new name of the Soviet psychiatric body] publicly acknowledges that previous political conditions created an environment in which psychiatric abuse occurred for non-medical, including political, reasons.

2. Victims of abuse shall have their cases reviewed within the USSR and also in cooperation with the WPA, and the registry shall not be used against psychiatric patients.

3. The All-Union Society unconditionally accepts the WPA review instrument [namely the upgraded procedure to be used by the Review Committee in investigating cases of psychiatric abuse].

4. The All-Union Society supports the changes in the Soviet law with full implementation relevant to the practice of psychiatry and the treatment and protection of the rights of the mentally ill.

5. The All-Union Society encourages an enlightened leadership in the psychiatric professional community."

Much confusion followed this statement. Delegates urged Dr Morozov to read it out again, slowly! Drs Sabshin and Birley remained dissatisfied. In the light of the first point in the statement, would $\mathrm{Dr}$ Morozov unequivocally admit that Soviet psychiatry had been misused for political purposes. Since none of the far more senior members of the delegation had even hinted as much, Dr Morozov (a relatively junior psychiatrist who had presumably been selected to represent the Society at the General Assembly because of his impeccable English!) was obviously not going to go beyond his remit. Delegates had heard the Soviet statement, he replied, and were in a position to come to their own conclusions. Thus, even at this pivotal stage, Soviet evasiveness prevailed.

Something of an impasse was the consequence of this interchange. Stefanis, backed by Professor Fini Schulsinger, the Association's Secretary-General and a leading proponent of unconditional admission, again reminded delegates that the sole question to be answered revolved around the 1983 resolution - had "amelioration" taken place or not? The two office bearers were clearly intent on deflecting the delegates from the matter of Soviet acknowledgement, and impatient for the issue of membership to be voted upon. They were however forced to contain their frustration as delegate after delegate insisted on contributing to the debate.

One camp remained persuaded that the time was not right for admission, conditional or otherwise. Dr John Grigor, the Australasian delegate, put it eloquently by avowing that: "Compromise is not always possible in ethical issues". The abuse continued to occur [indeed, a report by Amnesty International on human rights in the USSR published around that time (report EUR 46/22/89; 18 October 1989) referred to the prevalence of abuse, albeit on a reduced scale], and most of the discredited leadership still held office. The Canadian delegate, Dr Q. Rae-Grant, similarly argued that the problem had not gone away; although reforms had been instituted, the "product was limited". His compromise was to extend the status of ad hoc membership and to review further progress at the next General Assembly three years later.

Other delegates were inclined to be more generous to their Soviet colleagues, arguing for full membership but with certain conditions attached. Professor Lopez-Ibor, the Spanish delegate and newly appointed WPA Secretary-General, believed that further change would be more likely to occur if the Russians were within the organisation rather than outside it. It was also a question of trust.

After a seemingly interminable exchange, Professor Felice Lieh Mak, the delegate from Hong Kong and newly elected as the WPA's PresidentElect, proposed a motion which she hoped would serve as a suitable compromise. The Russian statement would be incorporated as a preamble and be accompanied by the following statement:

"Whereas the WPA is already on record that it will accept as full members only those societies that subscribe to the review instrument.

Therefore be it resolved that the All-Union Society of Psychiatrists and Narcologists be accepted into membership on the following conditions:

1. A site visit by the WPA Review Committee be made within one year;

2. If the report indicates that psychiatric abuse for political purposes continues, a special meeting of the General Assembly be convened to consider the suspension of membership."

With the hour approaching midnight - some nine hours after the General Assembly meeting had begun, (and with the announcement that the interpreters would soon give up the ghost!), the weary delegates expressed their willingness to vote on the Lieh Mak motion. The result was overwhelming support for conditional membership, with 291 votes for, 45 against, and 19 abstaining. 
It took but a moment to admit the rival Independent Psychiatric Association to full membership. A mere six votes were cast against the proposal.

\section{Subsequent developments}

The major question following the General Assembly was (and remains) whether the Russians would indeed take the requisite steps to complete the reforms of their profession. Although the WPA would have the leverage through the Review Committee to apply pressure, there were residual doubts in the minds of many delegates. Such doubts must have escalated sharply upon reading the report in Izvestia (19 October 1989) on the day following the passing of the General Assembly's Resolution; the fact of full membership was cited but without any mention of the two conditions. The tally of votes for membership was described as "a sensation". Ironically, the Independent Psychiatric Association was reported to have been accorded only the status of temporary member.

Even more disconcerting was a press conference held in Moscow ten days later (Guardian press release, 27 October 1989). Dr Karpov who had repeatedly and skilfully evaded challenges put to him in Athens dismissed reports of systematic abuse and claimed that there had only been "individual cases" and "medical mistakes". There were no statistics on how many cases of abuse had occurred. Finally, and most ambiguously, it was only in the courts that abuse could be proven. He seemed to be suggesting that the onus was on dissenter-patients to follow a legal process in determining whether unjustifiable detention had occurred or not. But, Dr Gennady Milyokhin, who had also been a member of the Soviet delegation in Athens, conceded that of the $\mathbf{3 0 0}$ patients named by international human rights organisations, "practically all had left hospital".

The pattern of contradictory and confusing replies that we had grown accustomed to in Athens was obviously a feature of this press conference as well. How should we now evaluate the situation? The pessimists will no doubt point out that perestroika and glasnost have barely touched the Soviet psychiatric profession and that its leaders will continue to prevaricate, as has been their practice for so long. This may not be too surprising given their precarious position. After all, in denying the existence of the abuse for so many years, they have contributed to its continuation.

A more optimistic view leads to another scenario. At the highest political level (with Yury Reschetov a chief protagonist), the decision will be taken to cooperate fully with the WPA and its Review Committee in order to retain membership. Thus, all remaining dissenter-patients, currently estimated to be in the region of 50-60, will win their release in the months to come. Furthermore, a proportion of those clearly discredited psychiatric leaders who have in one way or another been associated with the abuse will be demoted or forced into retirement (it seems most unlikely that any will be brought to trial). The process may have already begun. The sudden removal of Dr Churkin from his post of Chief Psychiatrist in the Federal Ministry of Health probably resulted from his poor performance in handling Western criticism. Professor Georgy Morozov's absence in Athens was conspicuous and could be the prelude to his professional demise. Similarly, the fact that the customary apologist for Soviet psychiatry, Marat Vartanyan, was kept away from all public fora in Athens, suggests that he has become a liability. Further optimism may be derived from the anticipated role of the Independent Psychiatric Association. Members of this ethically radical organisation will take heart from recognition by the WPA, and persevere in their efforts to elevate the ethical status of their profession. Although it is likely that they will remain a small group, they do have the potential nevertheless to prod their colleagues in the All-Union Society into adopting a more diligent approach concerning reform.

The WPA itself has a pivotal role to play. As we have repeatedly seen, membership of this body is critical to the Soviet authorities, both political and psychiatric. The Review Committee (due to be nominated in the New Year by the new Executive Committee) should tackle its job with assiduity and determination. Its task of assessing the "ethical status" of Soviet psychiatry by October 1990 is an awesome responsibility, and here the Association's Executive Committee and Advisory Committee should provide every support.

It would be a tragedy if the WPA did not take the initiative, at a time when so many other aspects of Soviet society are undergoing radical transformation. This is unquestionably an unparalleled opportunity to bring to an end one of the most unsavoury chapters in the contemporary history of psychiatry.

\section{References}

Bloch, S. \& Reddaway, P. (1977) Russia's Psychiatric Hospitals. London: Gollancz.

(1984) Soviet Psychiatric Abuse: The Shadow Over World Psychiatry. London: Gollancz.

Gluzman, S. (1989) On Soviet Totalitarian Psychiatry. Amsterdam: International Association on the Political Use of Psychiatry (an interesting account of contemporary Soviet psychiatry, available from IAPUP, P.O. Box 3754, Amsterdam 1001 AN).

ReDdAWAY, P. (1989) The current situation in Soviet psychiatry regarding political abuses. Psychiatric Bulletin, 13, 529-532. 